\title{
Terpenoids from the roots of Ceriops tagal induces apoptosis through activation of caspase- 3 enzyme
}

\author{
Musa CHACHA \\ Institute of Marine Sciences, University of Dar es Salaam, P.O.Box 668, Zanzibar, Tanzania. \\ E-mail: chacha@ims.udsm.ac.tz
}

\begin{abstract}
Dolabr-4(17),15(16)-dien-3-one, isopimar-8(14)-en-15,16-diol, isopimar-8(14)-en-16-hydroxy-15-one,

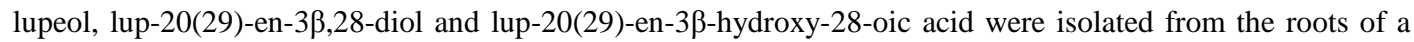
marine mangrove Ceriops tagal (Rhizophoraceae). The compounds were evaluated for activation of caspase-3 enzyme using Caspase-3 Colourimetric Assay. Caspase-3 enzyme was activated by all compounds in cleaving $p$ NA from Ac-DEVD- $p$ NA in the presence of caspase-3-inhibitor; Ac-DEVD-CHO. Lup-20(29)-en-3 $\beta$ hydroxyl-28-oic acid, isopimar-8(14)-en-15,16-diol and isopimar-8(14)-en-16-hydroxy-15-one cleaved 41.7, 39.42 and $34.19 \mu \mathrm{mol} / \mathrm{L}$ of $p \mathrm{NA}$ respectively. This study is therefore demonstrating that the isolated compounds may serve as leads for development of new chemotherapeutic drugs which acts by inducing apoptosis in the cancerous cells.

(c) 2011 International Formulae Group. All rights reserved.
\end{abstract}

Keywords: Ceriops tagal; terpenoids; apoptosis; caspase-3 activating.

\section{INTRODUCTION}

Apoptosis is an essential and highly conserved mode of cell death that is important for normal development, host defense and suppression of oncogenesis (Zhang et al., 2004). Faulty regulation of apoptosis has been implicated in degenerative conditions, vascular diseases and cancer (Ameisen et al., 1995; Thompson, 1995). Apoptosis is characterized by a variety of cellular changes including loss of membrane phospholipid asymmetry (Vermes et al., 1995; CosciolaRosen et al., 1996), chromatin condensation, mitochondrial swelling and DNA cleavage (Pan, 2001; Halicka, 2005). The end result of these changes is a form of cell death that avoids the normal inflammatory response associated with necrosis. Caspase- 3 is an intracellular cysteine protease that exists as a proenzyme, becoming activated during the cascade of events associated with apoptosis. Caspase-3 cleaves a variety of cellular molecules that contain the amino acid motif DEVD such as poly ADP-ribose polymerase (PARP). The presence of caspase-3 in cells of different lineages suggests that caspase- 3 is a key enzyme required for the execution of apoptosis (Fernendes-Alnemri et al., 1994).

The link between apoptosis and cancer was established in 1990 after the discovery that cancerous cells produce a protein that blocks apoptosis (Schulze-Bergkamen and Krammer, 2004). It was thereafter established that increase in cell division was not the only 
way that tumours could develop, but rather cells could also become potent promoters of tumour growth by avoiding programmed cell death (Lowe and Lin, 2000). Thus, compounds that activate caspase- 3 activity are promising candidates for cancer treatment. Plants and microorganisms are potential sources of such compounds of which most of them are terpenoids (Luo et al., 2002; Nagashima et al., 2003; Kondoh et al., 2004; Suzuki et al., 2004; Guzman et al., 2005; Lavrik et a., 2005; Heras et al., 2007). It is in this vein that dolabr-4(17),15(16)-dien-3-one (1), isopimar-8(14)-en-15,16-diol (2), isopimar-8(14)-en-16-hydroxy-15-one (3), lupeol (4), lup-20(29)-en-3 $\beta, 28$-diol (5) and lup-20(29)-en-3ß-hydroxy-28-oic acid (6) from the roots of Ceriops tagal (Perr.) C.B. Robinson (Rhizophoraeae) were evaluated for their activity in activating caspase- 3 . The aim of this study was to establish compounds which can either be used as templates for development of anticancer agents which act by inducing apoptosis of cancerous cells through the activation of caspase- 3 enzyme.

\section{MATERIALS AND METHODS \\ Plant material}

Roots of Ceriops tagal were collected from Maruhubi Mangrove Reserve, Zanzibar, Tanzania. The plant material was collected and authenticated by Mr. Muhidini Mtumwa of the Institute of Marine Sciences, University of Dar es Salaam. Voucher specimen (CT 03 2010) has been deposited in the Institute of Marine Sciences, University of Dar es Salaam.

\section{Extraction, isolation and identification of compounds}

The air dried roots of C. tagal (740.5 g) were pulverized and shaken in chloroform at room temperature for twenty four hours and the extract was concentrated under reduced pressure to afford $120.5 \mathrm{~g}$ of brown extract. The obtained extract was adsorbed on $150 \mathrm{~g}$ of silica gel and applied to a silica gel column packed with $1200 \mathrm{~g}$ of silica gel using $\mathrm{CHCl}_{3}$.
The column was eluted using $\mathrm{CHCl}_{3}$ [fractions 1-22] and $\mathrm{CHCl}_{3} /\left(\mathrm{CH}_{3}\right)_{2} \mathrm{CO}$ (1:1) [fractions 23-25]. Based on the TLC analysis, fractions were combined as follows: A (fractions 1-19), B (fractions 20-22) and C (fractions 23-25). The combined fraction $\mathrm{A}$ was passed through column chromatography using Sephadex LH 20 eluted with $\mathrm{CHCl}_{3} / \mathrm{MeOH}$ to afford lupeol (15.8 mg), lup-

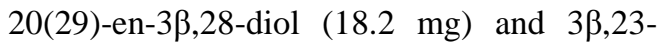
dihydroxy-20(29)lupen-28-oic acid (21.2 mg). The combined fractions B (20.6 g) was adsorbed on silica gel and packed on a silica gel column eluted with $n$-hexane/acetone (10:1) to give fractions B1 and B2. Fraction B1 was left in a conical flask for 36 hours, colourless crystals formed and were recrystallised in methanol to give isopimar8(14)-en-15,16-diol (46.8 mg). The combined fraction C $(15.4 \mathrm{~g})$ was adsorbed on silica gel and packed on silica gel column eluted with $n$ hexane/acetone (10:2) to give fractions $\mathrm{C} 1$ and $\mathrm{C} 2$. Fractions $\mathrm{C} 1$ and $\mathrm{C} 2$ were left overnight and colourless crystals developed which were then recrystallised in methanol and identified as isopimar-8(14)-en-16hydroxy-15-one $(10.3 \mathrm{mg})$ and erythroxyl4(17),15(16)-dien-3-one (39.5 $\mathrm{mg})$ respectively. Chemical structures of compounds 1-6 were established on the basis of spectroscopic data analysis (NMR, HEEIMS and Circular Dichoism Spectroscopy).

\section{Caspase-3 activity}

The Calbiochem caspase-3 assay kit was used to measure the protease activity of caspase-3. Components of the kit were; assay buffer (supplied as $20 \mathrm{ml}$ of $100 \mathrm{mM} \mathrm{NaCl}, 50$ mM HEPES, $10 \mathrm{mM}$ DTT, $1 \mathrm{mM}$ EDTA, $10 \%$ glycerol, 0.1\% CHAPS, pH 7.4), caspase-3 (1000 units/ $\mu 1)$, caspase substrate I (Ac-DEVD- $p \mathrm{NA}, 2 \mathrm{mM}$ ), caspase-3 inhibitor I (Ac-DEVD-CHO, $100 \mu \mathrm{M}$ ) and 96-well plate. All kit components were thawed and kept in ice bath until use (kit components are stable for several hours in an ice bath). Caspase-3 inhibitor I was briefly warmed to room temperature. Caspase-3 inhibitor I, 
caspase-3 enzyme and caspase substrate were diluted for use as follows: using microcentrifuge, caspase-3 inhibitor was diluted to $0.5 \mu \mathrm{M}$ by adding $1 \mu \mathrm{L}$ inihibitor to $200 \mu \mathrm{L}$ assay buffer; $5 \mu \mathrm{L}$ of caspase-3 was diluted to $245 \mu \mathrm{L}$ assay buffer and $1 \mu \mathrm{L}$ of Ac-DEVD- $p$ NA was diluted to $400 \mu \mathrm{L}$ (5 $\mu \mathrm{M})$ in the assay buffer. The diluted AcDEVD-pNA was equilibrated to assay temperature, $30{ }^{\circ} \mathrm{C} .50 \mu \mathrm{L}$ of the assay buffer was added to each well in a microplate reader and allowed to equilibrate to assay temperature, $30{ }^{\circ} \mathrm{C} .25 \mu \mathrm{L}$ of caspase- 3 was added to the control, inhibitor and test sample wells followed by the addition of Ac-DEVD$\mathrm{CHO}$ to the appropriate wells. The desired volume of test sample (dissolved in DMSO) was added to appropriate wells and the plate was incubated at $30{ }^{\circ} \mathrm{C}$ for 10 minutes to allow inhibition/enzyme interaction. The reaction was started by the addition of $50 \mu \mathrm{L}$ of Ac-DEVD- $p$ NA in each well. Compounds 1-6 were tested at three concentrations; stock solution $(1 \mathrm{mg} / \mathrm{ml}), 1 / 10$ dilution $(0.1 \mathrm{mg} / \mathrm{ml})$ and $1 / 100$ dilution $(0.01 \mathrm{mg} / \mathrm{ml})$ and each concentration in triplicate. Absorbance was recorded at $405 \mathrm{~nm}$ after 10 minutes, 30 minutes, 1 hour, 2 hours and 12 hours. The Microplate Reader uses Beer's Law to calculate the absorbance value of each well. The values of absorbance recorded were blank-corrected.

\section{RESULTS}

The pulverized roots of Ceriops tagal was subjected to chromatographic and gel filtration techniques to give six terpenes (Figure 1) of which dolabr-4(17),15(16)-dien3-one (1), isopimar-8(14)-en-15,16-diol (2), isopimar-8(14)-en-16-hydroxy-15-one (3) are diterpenes whilst lupeol (4), lup-20(29)-en-

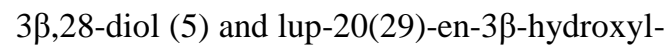
28-oic acid (6) are triterpenes. Compounds 12 were isolated for the first time from the leaves of Isdon flavidus (Zhao et al., 1998) whereas compound $\mathbf{3}$ was reported for the first time from the roots of Ceriops tagal (Chacha et al., 2008). Compounds 4-6 are the most widespread pentacyclic triterpenes and have been reported to have antineoplastic activity, trypsin and chymotrypsin inhibition activity (Sidiqui et al., 1988; Hata et al., 2003a, 2003b; Aratanedemuge et al., 2004). Lup20(29)-en-3 $\beta$-hydroxy-28-ioc acid has also reported to have anti-human immunodeficiency virus (anti HIV) activity (Fujioka et al., 1994).

These compounds were evaluated for the activation of caspase- 3 in cleaving pNA from acetyl-Asp-Glu-Val-Asp p-nitroanilide (Ac-DEVD-pNA) in the presence of the caspase-3 inhibitor Ac-DEVD-CHO. The DEVD amino acid sequence is derived from the caspase-3 cleavage site in Poly (ADPribose) polymerase (PARP). The released $p$ NA from the substrate was detected at 405 $\mathrm{nm}\left(\varepsilon_{\mathrm{mM}}=10.5\right)$ and its concentration was calculated from the absorbance mean values. The cleavage of the caspase-3-specific colorimetric substrate (DEVD- $p$ NA) was therefore considered to represent caspase-3 activity.

Figures 2, 3 and 4 show that all tested compounds enhanced activity of caspase- 3 in a concentration dependant manner. Figure 1 depicts the amount of $p$ NA released when compounds were tested at $0.01 \mathrm{mg} / \mathrm{ml}$. All compounds exhibited lower activity compared to the positive control but higher than negative control indicating the effects of caspase-3 inhibitor, Ac-DEVD-CHO (Figure 2). At concentrations of $0.1 \mathrm{mg} / \mathrm{ml}$ and $1 \mathrm{mg} / \mathrm{ml}$, all tested compounds exhibited higher activity as compared to the positive control confirming the involvement of terpenes in the activation of caspase-3 enzyme. Lup-20(29)-en-3 $\beta$ hydroxyl-28-oic acid $\mathbf{6}$ displayed higher activity than all tested compounds at 0.1 $\mathrm{mg} / \mathrm{ml}$. It increased the activity of caspase- 3 as time of incubation increased; the concentration of $p \mathrm{NA}$ released was 8.76, 12.19 and $12.66 \mu \mathrm{mol} / \mathrm{l}$ after 30, 60 and 120 minutes respectively (Figure 3 ). At $1 \mathrm{mg} / \mathrm{ml}$, all compounds exhibited much higher activity with the increase in the incubation time (Figure 4). 
<smiles>C=C[C@]1(C)CC[C@H]2[C@@H](C)CCC(=O)C(=C)[C@@]2(C)CC1</smiles>

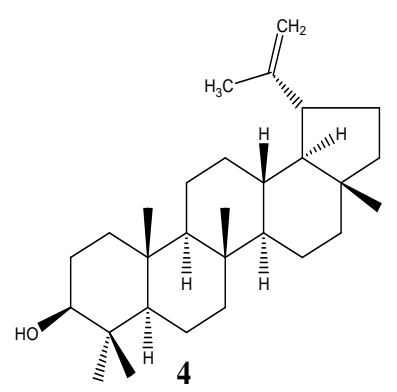

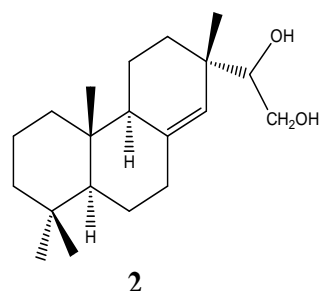

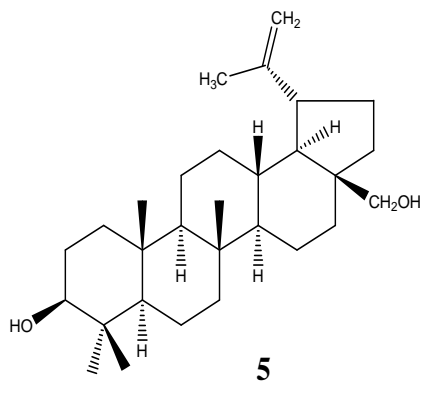

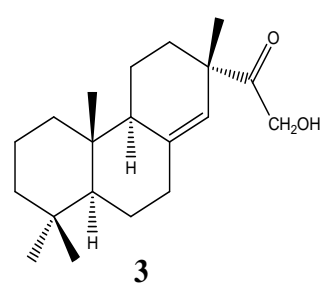

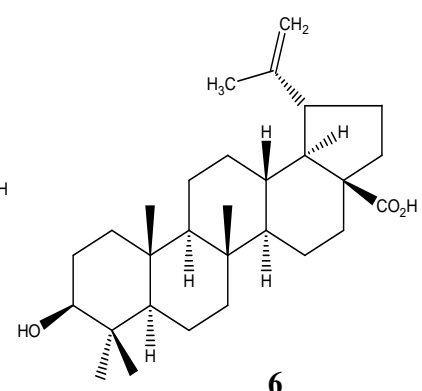

Figure 1: Structures of terpenoids 1-6 isolated from the roots of Ceriops tagal.

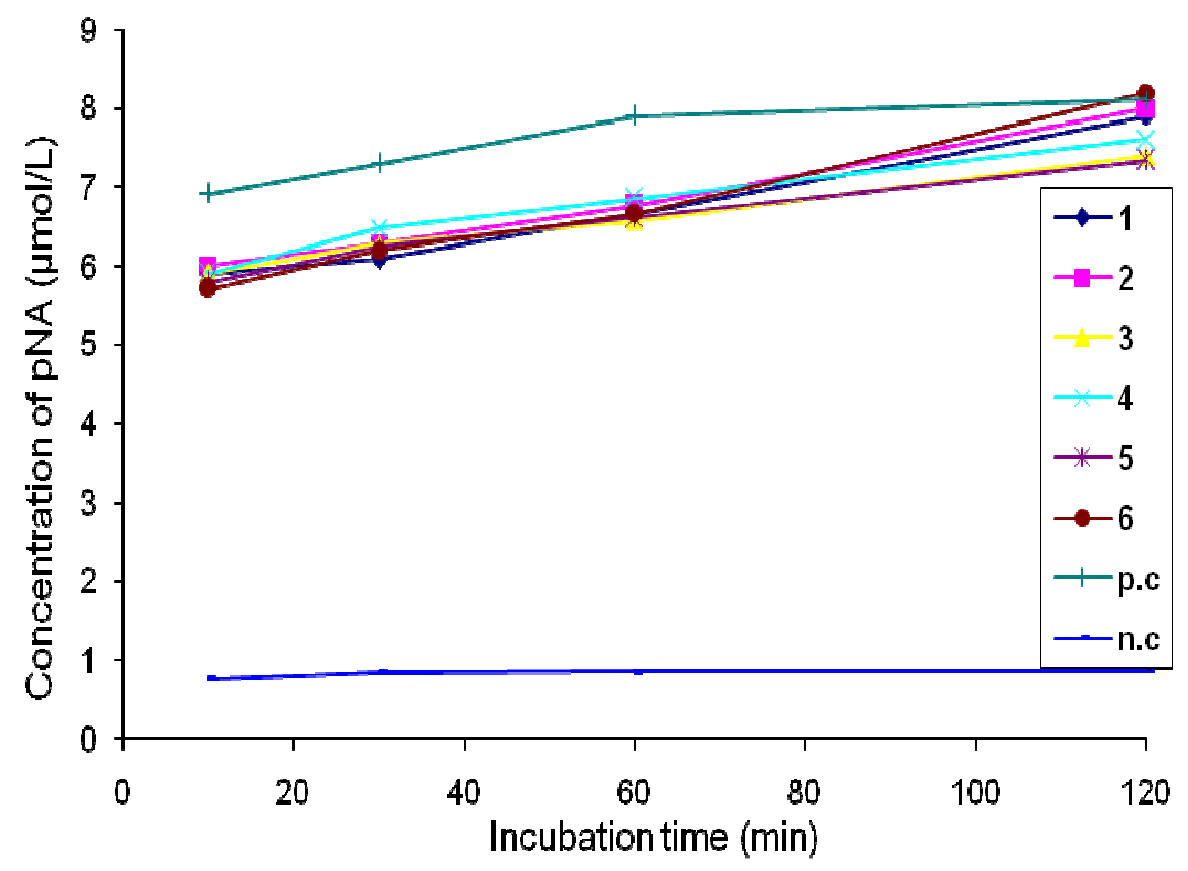

Figure 2: Caspase-3 activity at $0.01 \mathrm{mg} / \mathrm{ml}$ of compounds 1-6. 


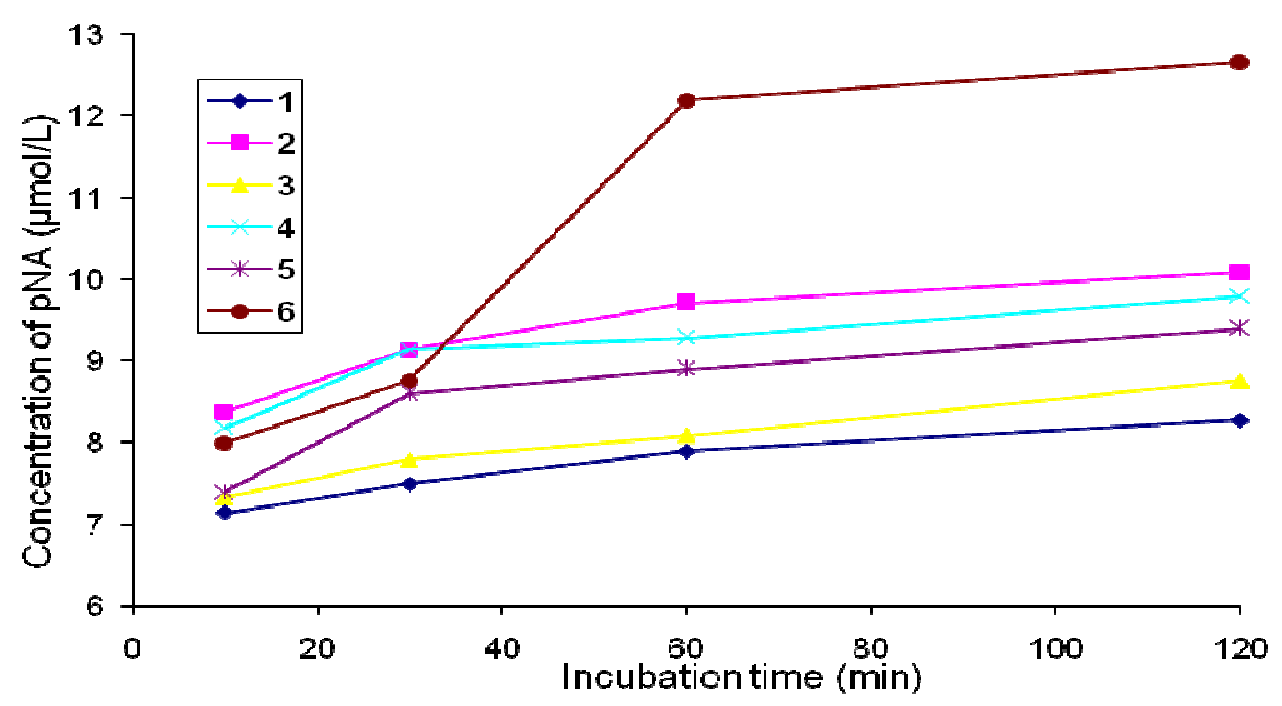

Figure 3: Caspase-3 activity at $0.1 \mathrm{mg} / \mathrm{ml}$ of compounds 1-6.

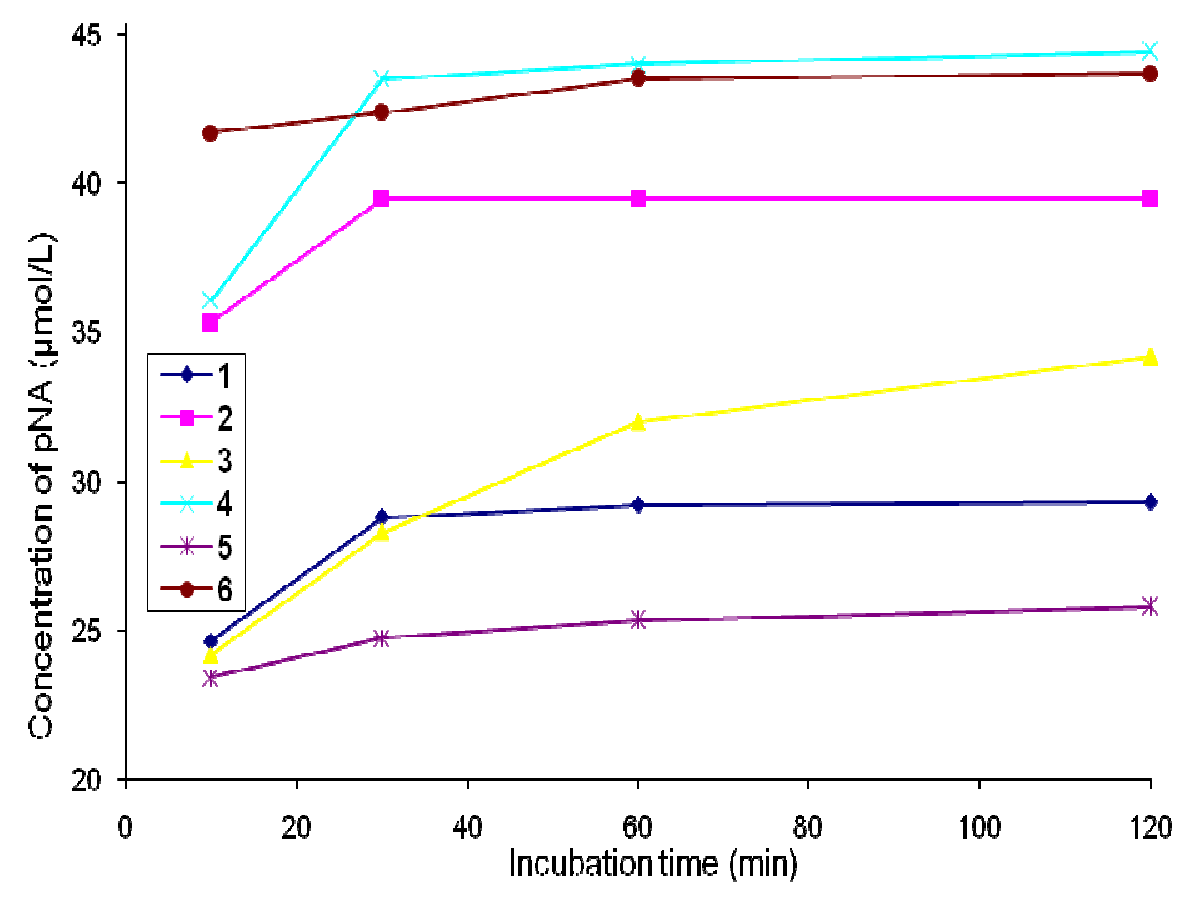

Figure 4: Caspase-3 activity at $1 \mathrm{mg} / \mathrm{ml}$ of compounds 1-6. 


\section{DISCUSSION}

The antitumor activity of terpenoids was first discovered over 35 years ago, when extracts from the stem barks of various terrestrial plants were tested for cytostatic activity using different in vivo cancer model systems (Schulze-Bergkamen and Krammer, 2004). At that time and until 1990, the target for compounds with anticancer activity was to inhibit cell division which was seen as the only way in which cancerous could develop and propagate. The establishment that cancerous cells produce a protein that blocks apoptosis has created another avenue in the fight against cancer. It has lead to isolation of compounds which induces activation of apoptosis through activation of caspases, a family of proteases which plays a central role in the initiation and activation of the apoptotic pathway (Pan et al., 2001; Nagashima et al., 2003; Zhang et al., 2004; Duarte et al., 2009).

In the present study, a relationship between structure and activity of terpenoids 1 6 on activation of caspase-3 has been established and has lead to a suggestion that the difference in the activation of caspase- 3 exhibited by these compounds is probably due to the difference in their structures. Isopimar8(14)-en-15,16-diol 2 with two hydroxyl groups at positions 15 and 16 demonstrated higher activity as compared to isopimar-8(14)en-16-hydroxy-15-one 3 which has an enone group at position 15 . Isopimaranes 2 and 3 enhanced caspase- 3 strongly as compared to dolabr-4(17),15(16)-dien-3-one 1 at all tested concentrations, which suggests that activation of caspase- 3 increases with the increase in oxygenation of diterpenes. This study has also revealed that hydroxylation at C-28 of triterpenes tends to lower caspase- 3 activity as indicated by lupeol 4 and lup-20(29)-en3ß,28-diol 5. It was also evident that carboxylation at C-28 markedly enhanced the activation of caspase- 3 as indicated with the activity displayed by caspase- 3 under the

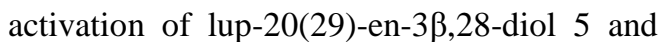
lup-20(29)-en-3 $\beta$-hydroxyl-28-oic acid 6 . Structure activity correlations for lupanes tested earlier on the activation of caspase- 8 and 9 revealed the same trend (Aratanechemuge et al., 2004; Hata et al., 2003a). However this is the first time for compounds 1-6 to be evaluated for the induction of apoptosis through the activation of caspase-3 enzyme.

\section{Conclusion}

This study has demonstrated that activation of caspase-3 enzyme is involved in terpenoids induced apoptosis and oxygenation is important for the activation of caspase-3 enzyme. It is therefore evident that terpenes may serve as leading compounds for the development of new chemotherapeutic drugs, which acts by inducing apoptosis in cancerous cells.

\section{ACKNOWLEDGMENTS}

I thank Muhidini Mtumwa for collection and identification of the plant materials. I am also grateful to Kisakasaka Mangrove conservation group for a permission to collect plant materials in the Kisakasaka Mangrove Reserve Forest.

\section{REFERENCES}

Ameisen JC, Estaquier J, Idziorek T, De Bels F. 1995. The relevance of apoptosis to AIDS pathogenesis. Trends Cell Biol., 5(1): 27-32.

Aratanechemuge Y, Hibasami H, Sanpin K, Katsuzaki H, Imai K, Komiya T. 2004. Induction of apoptosis by lupeol isolated from mokumen (Gossampinus malabarica L. Merr) in human promyelotic leukemia HL-60 cells. Oncol Rep., 11(2): 289-292.

Chacha M, Mapitse R, Afolayan AJ, Majinda RRT. 2008. Antibacterial diterpenes from 
the roots of Ceriops tagal. Nat. Prod. Commun. 3(1): 17-20.

Cosciola-Rosen LA, Nicholson D, Chong T, Rowan KR, Thornberry NA, Miller DK, Rosen A. $1996 . \quad$ Apopain/CPP32 cleaves proteins that are essential for cellular repair: A fundamental principle of apoptotic death. J. Exp. Med., 183(5): 1957-1964.

Duarte N, Ramalhete C, Varga A, Molnár J, Ferreira MJ. 2009. Multidrug resistance modulation and apoptosis induction of cancer cells by terpenic compounds isolated from Euphorbia species. Anticancer Res. 29(22): 4467-4472.

Fernandes-Alnemri T, Litwack G, Alnemri ES. 1994. CPP32, a novel human apoptotic protein with homology to caenorhabditis elegans cell death protein Ced-3 and mammalian interleukin-1Bconverting enzyme. J. Biol. Chem., 269(49): 30761-30764.

Guzman ML, Rossi RM, Karnischky L, Li X, Peterson DR, Howard DS, Jordan CT. 2005. The sesquiterpene lactone parthenolide induces apoptosis of human acute myelogenous leukemia stem and progenitor cells. Blood, 105(11): 41634169.

Halicka HD, Huang X, Traganosa F, King MA, Dai W, Darzynkiemicz Z. 2005. Histone H2AX Phosphorylation after cell irradiation with UV-B: Relatioship to cell cycle phase and induction of apoptosis. Cell Cycle 4(2): 339-345.

Hata K, Hori K, Ogasawara H, Takahashi S. 2003a. Anti-leukemia activities of lup-28ol-20(29)-en-3-one, a lupane triterpene. Toxicol Lett., 143(1): 1-7.

Hata K, Hori K, Takahashi S. 2003b. Role of p38 MAPK in lupeol induced B16 2F2 mouse melanoma cell differentiation. $J$ Biochem., 134(3): 441-445.

Heras B, Hortelano S, Girón N, Bermejo P, Rodríguez B, Boscá L. 2007. Kaurane diterpenes protect against apoptosis and inhibition of phagocytosis in activated macrophages. Br. J. Pharmacol., 152(2): 249-255.

Kondoh M, Suzuki I, Sato M, Nagashima F, Simizu S, Harada M. 2004. Kaurene diterpene induces apoptosis in human leukemia cells partly through a caspase-8dependent pathway. J. Pharmacol. Exp. Therm., 311(1): 115-122.

Lavrik IN, Golks A, Krammer PH. 2005. Caspases: pharmacological manipulation of cell death. J. Clin. Invest., 115(10): 2665-2672.

Lowe SW, Lin AW. 2000. Cancer biology. Carcinogenesis, 21(3): 485-495.

Luo Y, Smith JV, Paramasivam V, Burdick A, Curry KJ, Buford JP, Khan I, Netzer WJ, $\mathrm{Xu} \mathrm{H}$, Butko P. 2002. Inhibition of amyloid- $\beta$ aggregation and caspase-3 activation by the Ginkgo biloba extract EGb 761. Proc. Natl. Acad. Sci., 99(19): 12197-12202.

Nagashima F, Kondoh M, Kawase M, Simizu S, Osada H, Fujii M. 2003. Apoptosisinducing properties of ent-kaurene-type diterpenoids from the liverwort Jungermannia truncate. Planta Med., 69 (11): 377-379.

Pan MH, Chang WL, Lin-Shiau SY, Ho CT, Lin JK. 2001. Induction of apoptosis by garcinol and curcumin through cytochrome $\mathrm{C}$ release and activation of caspases in human leukemia HL-60 cells. J. Agric. Food Chem., 49(3): 1464-1474.

Schulze-Bergkamen H, Krammer PH. 2004. Apoptosis in cancer-implication for therapy. Semin. Oncol., 31(1): 90-119.

Siddiqui S, Hafeez F, Begun S, Sidddiqui BS. 1988. Oleanderol, a new pentacyclic triterpene from the leaves of Nerium oleander. J. Nat. Prod. 51(2): 229-233.

Suzuki I, Kondoh M, Harada M, Koizumi N, Fujii M, Nagashima F. 2004. An entkaurane diterpene enhances apoptosis 
induced by tumor necrosis factor in human leukemia cells. Planta Med., 70(8): 723-727.

Thompson CB. 1995. Apoptosis in the pathogenesis and treatment of disease. Science, 267(5203): 1456-1462.

Vermes I, Haanen C, Steffens-Nakken H, Reutelingsperger C. 1995. A novel assay for apoptosis. Flow cytometric detection of phosphatidylserine expression on early apoptotic cells using fluorescein labelled
Annexin V. J. Immunol. Meth., 18(1): 3951.

Zhang C-L, Wu L-J, Tashiro S-I, Onodera S, Ikejima T. 2004. Oridonin induces apoptosis of HeLa cells via altering expression of $\mathrm{Bcl}-2 / \mathrm{Bax}$ and activating caspase-3/ICAD pathway. Acta. Pharmacol. Sin., 25(5): 691-698.

Zhao Q, Tian J, Yue J, Chen S, Lin Z, Sun H. 1998. Diterpenoids from Isodon flavidus. Phytochemistry, 48(6): 1025-1029. 